\title{
Integrating Energy Markets in the Wider Europe: The Eastern Dimension ${ }^{1}$
}

\author{
Afroditi Semkou ${ }^{a}$, Elias Kolovos ${ }^{a}$, Ilias Andreadis ${ }^{a}$ and Anna Konstantinidou ${ }^{\mathrm{b}}$
}

\begin{abstract}
This paper examines the extent of integration between the regional energy markets of the Member States of the European Union and the countries of the wider Europe with special attention to the Eastern Partnership. Therefore, whether the aforementioned energy markets are in a position to conform to the acquis communautaire and ensure the security of energy supply to the EU in affordable prices. We will record what needs to be done for the integration of these regional energy markets with the EU common market and specifically: (a) the legal framework of the Eastern European non-EU regional energy markets, from the perspective of energy, trade and free competition. The impediments integration is facing and under which circumstances can it be achieved. (B) The required infrastructure and connectivity networks necessary to be completed in order to allow the utilization of the energy reserves in the third countries and the network connection of these third countries with the EU. The designated Trans European Network Strategy regarding the sectors of electricity, natural gas, oil and the Projects of Common Interest currently being constructed in Eastern Europe. (C) The promotion of investments that needs to be carried out in the wider European countries in order to ensure security of energy supply of the EU in the long term. The various forms of cooperation agreements between Georgia, Moldova, Ukraine, Armenia, Belarus and Azerbaijan with the EU and their contribution to the promotion of energy investments and the interconnection of cooperation agreements with the Energy Community.
\end{abstract}

Keywords: EU, Eastern Europe, Free Trade Agreements, Infrastructure, TEN - E, PCI, Promotion of Investments

\section{Introduction}

The present paper is based on three assumptions:

A. The European Union constitutes an internal, integrated energy market that is composed of the energy markets and industries of the EU Member States that operate and function within the framework of the single European energy market. The European Energy Union has its own rules and institutions. The independent energy regulators of each Member State are of paramount importance and coordinated by the European Commission in order to regulate national energy markets of the Member States. The European Energy Union thus falls within a uniform legal order, geographically EU-wide, that guarantees the same playing rules and terms of competition for the players in the EU's single energy market field.

B. The internal European energy market still has a long way to go in order to conform to the single energy market objective, where all actors are subject to the same Pan-

${ }^{1}$ This is a research co-financed by Greece and the European Union (European Social Fund - ESF) through the Operational Program «Human Resources Development, Education and Lifelong Learning 2014- 2020» in the context of the project MIS 5005494. Prof. Panayotis Glavinis supervised the said research. 
European operating rules. This is because, unlike the example of telecommunications, where the European market has been fully opened and massively privatized and harmonized, the European energy market still remains divided into national energy markets to a certain extent, since national energy networks are not fully interconnected. This technical reason that keeps the energy markets divided, also affects the regulation of the single European energy market that is not able to reach the maximum integration level, unless it follows the telecommunication market formula, under which the telecommunication grids have been interconnected in a Pan-European level, thanks to the progress of technology. As a result, national energy markets of the EU Member States, should operate as interconnecting pipes, where the same level of liquid inside the pipe, will suggest the absolute harmonization of operational rules, pursuant to the national legal order and institutions.

C. EU is energy dependent on sources located in third countries, where energy is produced and transported to Europe where it is actually consumed. These countries are neighboring with the EU and geographically placed in the area called Wider Europe. However, the markets of these countries are not governed by the European law as because they are outside the EU. For the security of supply and the smooth and predictable operation of the energy market, the European energy acquis needs to be extended to non-member neighboring countries and form single regional markets. Thus, the EU is geographically close to neighboring countries that own energy reserves, in the North (Norway), East (Russia, Ukraine, Belarus, Moldova, Caucasus), Southeast (Western Balkans, Turkey), Middle East (Israel, Syria) of course and South (the countries in the southern Mediterranean basin).

Taking the aforementioned into account, we come to the conclusion that energy interconnection of the countries of the wider Europe with the markets of the EU Member States requires that the regional energy markets created on both sides of the European frontier, be subject to the same operating rules in order to ensure an uninterrupted flow of sufficient energy resources to Europe at reasonable market prices. EU considers that its global energy interests are better served when other countries incorporate the operational rules of its internal market. This provides a framework of stability and predictability and that is the reason why the EU has signed a plethora of bilateral agreements with the Central Asian states, Azerbaijan, Algeria, Egypt and others. These agreements also reflect a geopolitical approach to energy security, with European suppliers reacting towards uncertainty by seeking more predictable long-term contracts with producers (R. Younds, 2013)

The popular demand is clear towards the integration of the EU's regional energy markets. To what extent have the critical regional energy markets been integrated with the countries of the wider Europe and what is still needed to be done for the harmonization of their function with the market of the EU?

a) Regional energy markets are being developed and operate within the framework of the EU's wider relations regarding the countries of the Wider Europe. To what extent are geopolitical conditions in these areas mature to welcome an enhanced process of integration of critical regional energy markets? How effective can the EU be in the exercise of energy diplomacy?

b) The EU has clear interest in promoting free competition in the countries of origin of 
the energy it consumes, because it encourages new investments in these countries, which will ensure adequate energy supply at cheap prices. However, in order to act outside its borders, as well as within its borders, the EU requires to have the necessary competence.

c) In order to integrate the regional energy markets lying at the external borders of the $\mathrm{EU}$, the harmonization of their operating rules is a priority. The tools that EU has at its disposal are regulation in combination with action to achieve the required degree of harmonization of the operating conditions of these markets.

d) What is also a prerequisite for the integration of energy markets in the Wider Europe is the development of cross-border infrastructure and connectivity networks among EU energy markets and the energy markets outside these borders. What is relevant, for the integration of the energy market within the EU, also applies to the integration of the markets outside the EU. There can be no internal energy market if it is not technically interconnected.

\section{Energy Markets Integration}

The European Union is an energy dependent entity, whose security of supply policy is of paramount importance for its energy sustainability. The import of energy into the Union requires an appropriate framework to facilitate cross-border, nondiscriminatory, equitable access to the networks and gradually the liberalization of energy markets. This liberalization has been the subject of constant regulation, geared to define a specific policy for the establishment of a single, integrated energy market. However, given the energy poverty of the latter, the development of cooperative relations with third countries that have higher energy potential, should be promoted.

The notion of European external governance is part of an agenda that concerns the interdependence between political units - in the present case the EU and respective third countries. EU neighborhood policies are characterized by a dual structure composed of, on the one hand, the overarching "macro policy", laying down the overall goals and instruments of these privileged relations, and the "meso policies", relating to the sectoral modes of interaction (S. Lavenex, D. Lehmkuhl and N. Wichmann, 2009). Whereas the "macro policies" result from coordinated, political processes of foreign policy-making, the "meso policies" reflect the external dimension of internal sectoral integration (S. Lavenex, D. Lehmkuhl and N. Wichmann, 2009). These external dimensions have usually been motivated as functionally-driven answers to situations of interdependence and to the externalities produced within the individual sectors such as the environment, energy, migration management, or the fight against organized crime and others (S. Lavenex, D. Lehmkuhl and N. Wichmann, 2009).

In the aforementioned framework, the Eastern Partnership is a joint initiative involving the EU, its Member States and six Eastern European Partners: Armenia, Azerbaijan, Belarus, Georgia, the Republic of Moldova and Ukraine. It is a specific dimension of the European Neighborhood Policy that focuses at structuring a common zone of shared democracy, prosperity, stability and increased cooperation. Furthermore, the relations established through the Eastern Partnership help fostering state and societal resilience so as both the EU and the partners are getting stronger against any challenges. 
While Partner Countries have different characteristics and diverse ambitions from the $\mathrm{EU}$, they also share important opportunities and challenges among which energy efficiency. Multilateral cooperation enables the exchange of best practices and intends to promote regional cooperation among partner countries and between them and the EU Member States (European Union External Action, European Partnership, 2019). When it comes to connectivity and energy efficiency, EU4Energy is an initiative for the above Eastern Partnership countries aiming to reduce energy dependence, bolster resilience and create opportunities for low-carbon economies. In this context, approximation of the regulatory framework for the increase of security supply, competitiveness and sustainability of the energy sector is of big significance. Such approximation contributes to the creation of a homogeneous, correspondent and stable regional legal framework, attracting large investments in the energy sector. Development of interconnections requires both a set of common rules in the energy sector and the construction of the necessary infrastructures.

\section{Eastern Countries' Relations with the EU}

Eastern Partnership is part of the European Neighborhood policy, which seeks to establish more effective partnerships between the EU and its neighbours towards a more stable EU Neighbourhood, in political, socio-economic and security terms (European Union External Action, European Neighborhood Policy, 2019). Its core objectives are differentiation among partner countries, flexibility, joint ownership, greater involvement of the EU Member States, shared responsibility and better access to the EU market for the partner countries.

\subsection{Armenia}

The EU-Armenia Comprehensive and Enhanced Partnership Agreement (CEPA), which was signed in the context of the Eastern Partnership Summit in Brussels, in November 2017 and entered into provisional application on 1 June 2018, constitutes the base for the relations between the European Union and Armenia. The latter text provides a framework for the European Union and Armenia to continue working together and takes into account the new global, political and economic interests shared by both sides.

\subsection{Azerbaijan}

The EU-Azerbaijan Partnership and Cooperation Agreement governs their relations. In February 2017, they began negotiations on a new framework agreement with Azerbaijan in order to foster beneficial cooperation. Joint policy priorities were set into forth on 28 September 2018 and they will guide and enhance their relations over the coming years. Azerbaijan plays a critical role in bringing Caspian energy resources to the EU market.

\subsection{Belarus}

Belarus is involved to the multilateral formats of the Eastern Partnership and the EU-Belarus Partnership Priorities, currently negotiated will foster better relations 
between the two. The EU is also in favor of Belarus' World Trade Organisation accession contributing to the creation of a more predictable business environment, attractive for investments.

\subsection{Georgia}

EU-Georgia relations are based on the EU-Georgia Association Agreement including a Deep and Comprehensive Free Trade Area (DCFTA), set in force from July 2016. The implementation of the outcomes of the High-level meeting between the European Commission and the Government of Georgia on 21 November 2018, will further ensure EU-Georgia relations.

\subsection{Moldova}

EU-Moldova Association Agreement and the 20 Deliverables for 2020 is linked to the country's reform commitments and aims at improving the quality of life in a tangible manner, strengthening the rule of law, as well as improving the business climate, with a view to reaping the benefits from the DCFTA and supporting greater connectivity between Moldova and the EU in the areas of energy and transport.

\subsection{Ukraine}

Constituting a part of the Association Agreement between the EU and the Republic of Ukraine, the Deep and Comprehensive Free Trade Area (DCFTA) is part of the Association Agreement between the EU and the Republic of Ukraine, one of EU's the most ambitious bilateral agreements, that will offer Ukraine a framework for updating its trade relations, removing customs tariffs and quotas, and harmonizing laws, norms and regulations in various trade-related sectors.

\section{The Association Agreements between Ukraine, Georgia and Moldova and the EU as a Tool for the Liberalization and Promotion of Investments in the Energy Sector}

The ultimate goal of the European Union within the Eastern Partnership is to create an internal market. The establishment of an internal market can be accomplished in a number of ways, such as by prohibiting discrimination and by harmonizing rules and technical standards. (R. Torino 2017) The AAs are the basic tool of the European Union for the integration of markets in the Eastern European region. The main economic pillar of AAs is the DCFTA, which has two key features: the gradual opening of markets by eliminating tariffs and non-tariff barriers and a careful regulatory approach to European Union law by attracting foreign investment and by encouraging the economic restructuring and development of the partner countries. (Commission Staff Working Document 2017).

The European Union has established a close co-operation with Ukraine, Moldova and Georgia as a result of the AAs signed in 2014. These three AAs, which differ little in their terms, bring these countries closer to the European Union than any other country and deepen the relations established under the pre-existing Partnership and Cooperation Agreements (S. Poli 2015). In fact, AAs with the three countries above have three 
specific characteristics: completeness, complexity and conditionality. The term completeness comprises of comprehensive framework agreements covering all EU activities from the creation of DCFTA, foreign policy cooperation to cooperation in the area of freedom, security and justice. The second feature shows that the aim of the agreements is to achieve economic integration in the EU's internal market through the establishment of the DCFTA and the acceptance of the Union's policies. This target requires a full legislative and regulatory approach including mechanisms to ensure the uniform interpretation and the effective application of European law in the legal systems of the states concerned. Finally, in terms of conditionality, AAs link directly the performance to areas, where partner countries have undertaken commitments with the progress of their integration into the European Union. These agreements involve a model of "market access" on terms that are directly linked to the legislative approach between European Union legislation and the laws of the states concerned (R. Petrov2016).

Based on the aforementioned observations and especially on the elements of complexity and conditionality, we can conclude that the key to achieve the overriding goals is to export the Community acquis (K. Wolczuk et al. 2017) and the obligation of third States to move towards the harmonization of their legislation with the corresponding provisions of European law. The export of the acquis communautaire inevitably raises the question of the analysis of this acquis, in relation to the matter under consideration, particularly the right of access to the market, known in energy law with the more specific term of third party access. Finally, it is commonplace that the creation of a free and open energy market is impossible without a powerful legal and regulatory framework (D. Dusciac et al. 2016).

All three association agreements establish and explicitly refer to the right of third parties to have access to energy infrastructures and to the obligation of the parties to adapt their legislation in order to secure the relevant third party access conditions. Particularly, in accordance with Articles 273 and 346 of the Association Agreements of Ukraine and Moldova, the Parties shall adapt their legislation, as referred to in the relevant Annex of the Agreement and in the Energy Community Treaty of 2005, in order to ensure that the tariffs, published prior to their entry into force, the capacity allocation procedures and all other conditions are objective, reasonable and transparent and shall not discriminate on the basis of origin, ownership or destination of the electricity or gas.

There is clear differentiation in the wording of the relevant Georgia agreement and specifically Art. 217, where there is a lack of reference in the Energy Community Treaty due to the fact that at the time of the negotiation of the agreement, Georgia was not a member of the Energy Community. Thus, the third party access to the market regulated in the third energy package and comprised part of the energy community legislation did not extend to Georgia. However, through the association agreement Georgia has had the obligation to apply the principle of third party access. (G.Van Der Loo 2017)

\section{The Relationship between the AAs, the Energy Community and the EU Law}

The participation of Ukraine, Georgia and Moldova in the Energy Community adds another dimension to the projections of the AAs. It is explicitly mentioned in the 
three Association agreements that, in the event of a conflict between the provisions of the association agreements and the energy community provisions or the provisions of the Union legislation applicable within the framework of the Energy Community, the provisions of the energy community or European law apply to the energy community prevail against the opposite terms of the AAs.

This primacy responds to the nature and mission of the energy community as the energy community aims to extend to the parties the implementation of the Community acquis in the field of energy. The intended goal is very ambitious, as it requires from the energy community members to produce important legislative work to achieve the incorporation of the acquis into their domestic law. In its annual reports, the Energy Community Secretariat records the progress of the Parties in the implementation of the EU energy acquis. However, the experience has shown that there are delays and fluctuations (G. Pavlidis 2012). Indicative is the Annual Implementation Document of the Secretariat of the European Community on the issue of third party access to networks. In Georgia, in the electricity sector, the third party access is only guaranteed for certain categories of system users. Access to the networks is based on the tariffs approved by the system regulator, while compliance rules for access to the system and congestion management have not been defined yet. As far as natural gas is concerned, an integrated system with transparent and non-discriminatory rules on the third party access to the networks has not been established yet. In Moldova, with respect to the field of electricity, tariffs are approved and published but the distribution of cross-border capacities with the Ukrainian system is not implemented in accordance with market principles and does not comply with Regulation 714/2009. In the natural gas sector there is no entry/exit pricing method while capacity allocation is not performed. Finally, in Ukraine in the gas sector, the third party access including transportation, storage and distribution is in place. However, the distribution pricing methodology as well as the tariffs for storage and entry/exit transfer to the grid should be updated and reflect the actual costs (Energy Community Secretariat 2018).

At the same time, apart from the specific provisions of the Association Agreements, the participation of the three states in the Energy Community provides an independent basis for the further promotion and liberalization of energy investments through the mechanisms and the law-making process within the Energy Community itself. Under the Energy Community regime, there are two types of the EU's "Energy Acquis". The first is the one defined in the Energy Community text and in the relevant annexes when the treaty was signed. The second type is the "dynamic energy acquis" that appears after the entry into force of the Energy Community Treaty.

With regard to the second form of the acquis, Article 25 of the Energy Community Treaty states the following:

"The Energy Community may take Measures to implement amendments to the acquis communautaire described in this Title, in line with the evolution of European Community law."

The use of the term "may" could potentially be considered to partially weaken the binding nature of the provision in question, but this does not diminish its importance for the legal order of the Energy Community. Under the provisions of Articles 89-93 of the Energy Community Treaty, if the Community institutions issue binding decisions, aiming 
at implementing the EU's "dynamic energy Acquis", the Community's contracting parties have the legal obligation to apply the decision, otherwise they will be subjected to the penalties provided by the relevant Treaty mechanism (R. Petrov 2012).

Finally, another provision contributing to the reinforcement of the integration process on its own and beyond the other commitments made by the Contracting Parties is Article 94 of the Energy Community Treaty, according to which the provisions of the Energy Community should be interpreted in the light of the case law of the Court of Justice of the European Union. Thus, the principle of direct effect as developed in the case-law of the Court of Justice of the European Union and the European Community should be applied within the framework of the Energy Community, when it reflects the corresponding provisions of the Treaty on the EU. In this way, the principle of nondiscrimination, a fundamental element of the third party access, has a direct effect within the Energy Community, to the extent that, according to the jurisprudence of the European Court of Justice, has a direct effect under the EU Treaty (R.Karova 2015).

\section{Energy Infrastructure Development}

Regarding the field of infrastructure and in conjunction with the further integration of energy markets in the wider Europe, to the common EU Energy Market, it is clear that the crucial infrastructure sector requires immediate and targeted interventions towards this end. It is obvious that the EU has undertaken initiatives such as the Trans - European Networks for Energy (TEN-E) Strategy and Regulation (EU) $347 / 2013$ for the further strengthening and integration of the internal market in order to enhance the security of the energy supply and diversify its energy suppliers. The aforementioned Regulation prescribes the compilation of a list of Projects of Common Interest. Therefore starting in 2013 and every two years the EU issues a new list of Projects of Common Interest. Unfortunately, however, only 12 of the 173 projects of the third PCI list, as it was issued in 2017, are directed towards the integration of Energy Markets in the wider Europe. Although very few compared to the total number of projects, under no circumstances are these projects of minor importance, on the contrary the projects demonstrate a clear intention of the EU towards integrating the Eastern part of the EU to the common market inseparable from the new EU Neighborhood Policy, by introducing two new major gas suppliers Azerbaijan and Turkmenistan to the EU energy market and a new major pipeline originating from the Middle East.

Within the framework of the following chapter we will briefly outline the TEN - E strategy and the Projects of Common Interest, whereas we will focus on the Southern Gas Corridor and the Projects of Common Interest included in it.

\section{TEN - E Strategy and the Projects of Common Interest}

The Trans-European Energy Networks (TEN-E) strategy focuses on developing, strengthening and linking the energy infrastructure of EU countries. Within the strategy, nine priority energy corridors and three priority thematic areas have been outlined. Regulation (EU) No 347/2013 of the European Parliament and of the Council on guidelines for trans-European energy infrastructure and specifically Art. 4 lays out the 
conditions under which infrastructure projects can be deemed as Projects of Common Interest and included in the relevant list. In addition, the aforementioned priority corridors must include at least two EU countries and require the urgent development of infrastructure in the electricity, gas or oil sectors. The priority themes identified are the development of smart grids, electricity and a cross-border carbon dioxide network.

The priority corridors laid out ion ANNEX I of the Regulation are as follows:

1. North Seas Offshore Grid (NSOG)

2. North-south electricity interconnections in western Europe (NSI West Electricity)

3. North-south electricity interconnections in central eastern and south eastern Europe (NSI East Electricity)

4. Baltic Energy Market Interconnection Plan in electricity (BEMIP Electricity)

5. North-south gas interconnections in Western Europe (NSI West Gas)

6. North-south gas interconnections in central eastern and south eastern Europe (NSI East Gas)

7. Southern Gas Corridor (SGC)

8. Baltic Energy Market Interconnection Plan in gas (BEMIP Gas)

9. Oil supply connections in central eastern Europe (OSC)

According to Art. 3 of the Regulation (EU) 347/2013, every two years, the EU compiles a "Union List" of projects of common interest. As stipulated in Art. 4 the criteria for the characterization of an infrastructure project as a PCI include the significant impact on energy markets and market integration in at least two EU countries, strengthening of competition in energy markets and helping EU energy security by diversifying its suppliers, as well as contributing to the EU's climate and energy goals through the integration of renewable energy sources. The selection process gives priority to projects in the priority corridors, as identified in the Trans-European Energy Networks (TEN-E) strategy. The Third List of Projects of Common Interest published in 2017, includes 173 projects, of which 106 electricity transmission and storage, 4 smart grid development, 53 natural gas, 6 oil and 4 cross-border carbon dioxide. The aforementioned list is also accompanied by a technical document providing more information on each individual project on its location, type and technology used for the implementation status and start dates. According to Art. 7 - 13 the selected projects can benefit from certain privileges such as faster planning and licensing procedures, a single national licensing authority, improved regulatory conditions, lower administrative costs due to improved environmental assessment procedures, increased public participation through consultations and increased visibility for investors. Finally, as prescribed in Art. 14, PCIs have access to the total amount of EUR 5.35 billion from the European Union's Connecting Europe Facility (CEF), the EU fund for the enhancement of energy, transport and digital infrastructure between 2014 and 2020.

\section{The Southern Gas Corridor}

When talking about the Southern Gas Corridor we refer to the "Infrastructure for the transmission of gas from the Caspian Basin, Central Asia, Middle East and eastern Mediterranean Basin to the EU to enhance diversification of gas supply.", as stipulated in ANNEX I \$2 section (7). 
The main infrastructure projects of the SGC are:

1. Trans-Caspian Gas Pipeline (TCP) (Turkmenistan - Azerbaijan)

2. South Caucasus Pipeline Future Expansion (SCPFX) (Azerbaijan - Georgia - Turkey)

3. Trans Anatolian Natural Gas Pipeline (TANAP) (Azerbaijan - Turkey - Greece)

4. EastMed Pipeline (Israel - Cyprus - Greece)

\subsection{Trans-Caspian Pipeline (TCP)}

TCP will be a 300-kilometer offshore pipeline crossing the Caspian Sea with a final capacity of 32 billion cubic meters, which will interconnect with the East-West pipeline in Turkmenistan and supply the Sangachal/SCP terminal in Azerbaijan (Technical information on Projects of Common Interest, 2018).

TCP will be an integral part both TANAP and TAP both of which are PCIs aimed at transporting natural gas from Turkmenistan and Azerbaijan, and potentially Kazakhstan and Uzbekistan. Both components of the cluster originate from Turkmenistan and using TCP, will connect to the expanded Southern Caucasus Pipeline Future Expansion (SCPFX) and then divide into two "bodies" that will provide two "penetration points" to the EU energy market. One of these entry points is through the system that includes the Trans-Anatolian gas pipeline (TANAP) across Turkey, as well as the Trans Adriatic Pipe (TAP) pipeline with Greece-Albania-Italy under the Adriatic Sea. The other point of entry is through the White Stream along the Black Sea. Gas from Turkmenistan will pass through the Caspian Sea in two phases. The idea of separating TCP natural gas in Georgia is called a "two entry-point approach" because it prescribes that Turkmen gas will be entering the EU markets in two different places. The two entry-point approach represents the diversification of the route to the Southern Gas Corridor (Trans-Caspian Pipeline, 2019)

\subsection{Southern Caucasus Pipeline Future Expansion (SCPFX)}

The SCPFX pipeline will be the upgrade of the existing SCP pipeline connecting Azerbaijan and Turkey via Georgia with an increased yearly capacity of 5 billion cubic meters by 2022. The already existing SCP pipeline has been operating since the end of 2006 transporting gas from Azerbaijan to Georgia and since July 2007 to Turkey by the Shah Deniz field. The current average daily capacity is 23 million cubic meters. The upgrade of SCP will include a new pipeline in Azerbaijan and two new compressor station in Georgia, causing a massive increase in the yearly yield of over 20 billion cubic meters (Technical information on Projects of Common Interest, 2018).

The South Caucasus pipeline (SCP) was originally built to transport gas from Azerbaijan (The Shah Deniz field) to Georgia and Turkey. The pipeline starts at Sangachal Terminal near Baku. It is part of the Baku-Tbilisi-Ceyhan (BTC) pipeline for the transportation of crude oil through Azerbaijan and Georgia in Turkey. The companies involved include:

1. The South Caucasus Pipeline Company (SCPC), responsible for the construction and operation of the entire pipeline

2. BP, responsible for the construction and operation of SCP's facilities and

3. SOCAR, responsible for the SCP business management.

(BP Azerbaijan. South Caucasus pipeline. 2019) 


\subsection{Trans-Anatolian Pipeline (TANAP)}

TANAP will be the new land and offshore pipeline between the eastern and western borders of Turkey with a length of $1807 \mathrm{~km}$ in the section, within the Turkish border, up to the Greek connection with the TAP Pipeline Project and an initial capacity of 16 billion cubic meters per annum (Technical information on Projects of Common Interest, 2018).

The goal of the TANAP pipeline is to transport natural gas from Azerbaijan's Shah Deniz-2 gas and other Caspian Sea areas, to Europe through Turkey. TANAP, together with the South Caucasus (SCP) pipeline and the Trans-Adriatic Pipe (TAP), PCIs included in the Southern Gas Corridor. TANAP consists of 19 kilometers of offshore pipeline extending under the Sea of Marmara, whereas the main pipeline within Turkey will reach a total of 1850 kilometers with 56 inch diameter pipes, transporting 16 billion cubic meters of gas annually. Six billion cubic meters will be used in Turkey, while the remaining ten billion cubic meters will be transported to Europe. The capacity of the pipeline is likely to increase to 24 billion cubic meters and then to 31 billion cubic meters in making additional investments (Trans Anatolian Natural Gas Pipeline Project, 2019).

\subsection{East Med}

EastMed will be an onshore and offshore natural gas pipeline about $1870 \mathrm{~km}$ long. The pipeline will have a capacity of $10 \mathrm{bcm} /$ year connecting Israel with the Greek mainland via Cyprus and Crete and at later stage with Italy and the rest of the EU energy market. The benefits of the project are also the reasons why it was selected as a PCI and include, but are not limited to, safeguarding the EU energy supply by exploiting the verified gas fields in the Cypriot EEZ and diversifying the supply of energy in the EU by exploiting the natural gas fields in the Levantine basin. The projection of the capacity of the pipeline is around 10 billion cubic meters of natural gas per year (Technical information on Projects of Common Interest, 2018).

IGI Poseidon, the company responsible for the planning of the pipeline has drafted the following preliminary design (IGI Poseidon, EastMed, 2019)

a. "200 km of maritime pipeline that extends from the shores of the Eastern Mediterranean towards Cyprus.

b. $700 \mathrm{~km}$ of water pipeline linking Cyprus with Crete.

c. $400 \mathrm{~km}$ of sea water from Crete to mainland Greece (Peloponnese).

d. $600 \mathrm{~km}$ of land pipeline crossing the Peloponnese and Western Greece."

\section{Concluding Remarks}

In a nutshell, having taken a brief overview of the regulatory framework established in these countries towards energy, we conclude that: The implementation of the acquis communautaire in the field of energy in the wider area we are studying is not massive. Other countries have fully implemented the acquis communautaire, others have selectively adopted some elements and others seem to have totally ignore it. These variations are likely to stem from a variety of reasons, such as intense political disorders that do not leave room for regulatory harmonization targets, or excessive government intervention to a degree that is inhibiting for the market liberalization, energy poverty or 
energy security of such a high level that makes alignment with the EU's regulatory framework unattractive.

In order to achieve the integration of the energy market at the above geographical zone, it would be useful to set some guiding norms, namely: efforts to ensure the implementation of EU legislation and the provisions of the Energy Community Treaty in the above countries. Also, the setup of "thematic groups" pointing out the key energy challenges, coordinating the drafting of national energy legislative plans, participating in the drafting of preparatory documents of new EU legislation, would provide necessary information regarding their regional dimension and their functioning should be established at a European level. The European Commission should support project development companies, trading platforms, professional associations and think tanks in the region, facilitating innovative projects by non-governmental actors within and outside the "thematic groups". Finally, the creation of a regional platform of companies from the countries concerned and other interested countries in the field of energy should be promoted.

\section{References}

BP Azerbaijan. South Caucasus pipeline. https://www.bp.com/en az/caspian/operationsprojects Lpipelines/SCP.html Accessed 24/06/2019.

Commission State Working Document (2017). Country Reports and Info Sheets on Implementation of EU Free Trade Agreement COM (2017) 645 Final, pp. 29-30.

Energy Community Secretariat (2018, September 1). Annual Implementations Report pp. 64, 66, 122, 124, 182.

D. Dusciac, N. Popescu, V. Parlicov (2016). EU-Russia and the Energy Dimension of the Eastern Partnership CES/CES Working Papers Volume VIII Issue 2, p. 259.

IGI Poseidon. EastMed. http://www.igi-poseidon.com/en/eastmed Accessed 24/06/2019.

European Union External Action. European Neighborhood Policy. https://eeas.europa.eu/diplomaticnetwork/northern-dimension/330/european-neighbourhood-policy-enp en Accessed 24/06/2019.

European Union External Action. European Partnership. https://eeas.europa.eu/diplomaticnetwork/eastern-partnership/419/eastern-partnership en Accessed 24/06/2019.

R. Karova (2015). The Application of the EU Constitutional principles in the Energy Community European Network Law and Regulation Quarterly (ENLR) Vol. 3 Issue 4 pp. 179-180.

S. Lavenex, D. Lehmkuhl and N. Wichmann. (2009). Modes of External Governance: A Cross-national and Cross-sectoral Comparison", Journal of European Public Policy, p.813-833.

G. Pavlidis (2012). Energy Community from the Fragmentation to the Regional Integration of Energy Markets in ENERGY Law, Economy and Policy, Edited by N. Farantouris Legal Library 2012, p. 349.

R. Petrov (2016). Implementation of Association Agreements between the EU and Ukraine, Moldova and Georgia: Legal and Constitutional Challenges in Political and Legal Perspectives of the EU Eastern Partnership Policy. T. Kerikmae - A. Chochia Editors Springer 2016, pp. 155-156.

R. Petrov (2012). Energy Community as a prompter of the European Union's “Energy Acquis”, Legal Issues of Economic Integration Vol.39 Number 3, pp. 340-342.

S. Poli (2015). The European Neighborhood Policy: A Differentiation without Political Conditionality, Yearbook of Polish European Studies Vol.18/2015, p. 139.

Regulation (EU) No. 347/2013 of the European Parliament and of the Council of 17 April 2013 on guidelines for trans-European energy infrastructure and repealing Decision No 1364/2006/EC and amending Regulations (EC) No 713/2009, (EC) No 714/2009 and (EC) No 715/2009. https://eur-lex.europa.eu/LexUriServ LLexUriServ.do?uri=OJ:L:2013:115:0039:0075:en:PDF Accessed 24/06/2019. 
Technical information on Projects of Common Interest accompanying the Commission Delegated Regulation (EU) 2016/89 of 18 November 2015 amending Regulation (EU) 347/2013 of the European Parliament and of the Council on guidelines for trans-European energy infrastructure as regards the Union list of projects of common interest. https://ec.europa.eu/energy/sites/ener/files/technical document 3rd list with subheadings.pd f Accessed 24/06/2019.

R. Torino (2017). Introduction to European Union Internal Market Law Roma Tre-Press, p. 9.

Trans Anatolian Natural Gas Pipeline Project. https://www.tanap.com/tanap-project/why-tanap/ Accessed 24/06/2019.

Trans-Caspian Pipeline. http://www.w-stream-transcaspian.com/the-project/ Accessed 24/06/2019.

K. Wolczuk, L. Delcour, R. Dragneva, K. Maniokas, D. Žeruoli (2017). The Association Agreements as a Dynamic Framework: Between Modernization and Integration, EU-STRAT Working Paper Series No.6 September 2017 p. 8.

G. Van Der Loo (2017, June 24). The EU Association Agreements and DCFTAs with Ukraine, Moldova and Georgia A Comparative Study p. 14 http://www.3dcftas.eu/ Accessed 24/06/2019.

R. Younds. (2013) A New Geopolitics of EU Energy Security, Carnegie Publications, 2013, p 4-5. 